Marzena ORŁOWSKA

Uniwersytet Warszawski

\title{
Neorealistyczne interpretacje procesu integracji europejskiej
}

\section{Neorealistic Interpretations of European Integration Process}

\begin{abstract}
Taking place within the European Union integration processes are the subject of research of many theorists of the European integration. On the basis of the social sciences, there are many theoretical approaches which try to explain the phenomenon of integrating Europe. However. this is a difficult task, because integration is a long and dynamic process, which requires the analysis from the several approaches. Also on the scientific ground is appropriate to use interdisciplinary apporoach to study this issue. Its complexity is confirmed by numerous European integration theories. While those grown on the gound of theories belonging to the theory of international relations. Therefore, they based on liberal or realistic approach. The best known and most widely used theoretical approach in the study of European integration is liberalism. Evidenced by the fact, that most modern integration theory and theoretical approaches derive precisely from the liberal paradigma. We are talking about such theories as neofucntionalism, institutionalism and liberal intergovernemntal approach. The purpose of this article is however, demonstrate the complexity of the integration process on the basis of the neorealistic interpretations of this issue. Therefore will be discussed concepts of H. Morgenthau, M. Mosser and J. Grieco.
\end{abstract}

Keywords: Europe, integration process, realism, liberalism, neorealism Słowa kluczowe: Europa, proces integracji, realizm, liberalizm, neorealizm

Dokonujące się w ramach Unii Europejskiej procesy integracyjne stanowią przedmiot badań wielu teoretyków integracji europejskiej. Na gruncie nauk społecznych istnieje wiele podejść teoretycznych, które starają się wyjaśnić zjawisko integrującej się Europy. Jest to jednak zadanie niezwykle trudne, bowiem integracja jest procesem długotrwałym. Wpływa na nią wiele czynników, które w wyniku różnych zmian same ulegają zmianom, co powoduje, że przebieg integracji również może być zmieniony. Tym samym śmiało można stwierdzić, że integracja jest zjawiskiem dynamicznym, wymagającym analizy z perspektywy kilku płaszczyzn. Integracja dotyczy bowiem zarówno sfery politycznej jak i ekonomicznej czy też społecznej. Jest to zatem nauka o interdyscyplinarnym charakterze. 
Wymaga ona od aktorów zaangażowanych w integrację współpracy, która ułatwić ma ten proces. Na poziomie narodowym związane to może być z dostosowywaniem specyfiki kraju w aspekcie politycznym, gospodarczym do wymogów Unii Europejskiej (np. implementacja unijnych procedur) ale także wymaga przystosowywania się w niewielkim stopniu Unii Europejskiej, w szczególności jej organów czy też sposobu funkcjonowania, do specyfiki państwa kandydującego. Dobrym przykładem takiego szczególnego przystosowywania się Unii Europejskiej do państwa kandydującego jest proces integracji Bułgarii z Unią Europejską ${ }^{1}$. Akcesja Bułgarii odbyła się bowiem na specjalnych warunkach, świadczą o tym różne podstawy prawne akcesji, a także instrumenty przed i poakcesyjne stosowane przez UE, np. klauzule ochronne w sprawach gospodarki i spraw wewnętrznych, czy też możliwość przesunięcia przystąpienia do UE w rok później od daty zakładanej w traktacie akcesyjnym.

Oprócz integracji w sferze proceduralnej, odbywa się ona także w wymiarze terytorialnym i społecznym. W tym przypadku integracja stanowić będzie bezpośrednie przyłączenie terytorium danego państwa do terytorium Unii Europejskiej jak też będzie stanowić integrację obywateli Unii Europejskiej w sferze społecznej, tożsamościowej².

Powyższe potwierdza wieloaspektowość procesu integracji i to, że również na gruncie naukowym właściwym jest podejście interdyscyplinarne w badaniu tej problematyki. Jej złożoność potwierdzają liczne teorie integracji europejskiej, które w zależności od tego, jakie aspekty integracji chcą analizować, kładą nacisk na konkretne, wybrane jej elementy. Wartym zaznaczenia jest fakt, że teorie integracji europejskiej wyrosły na gruncie teorii należących do dziedziny stosunków międzynarodowych. W związku z tym bazują na podejściu liberalnym lub realistycznym.

Najbardziej znanym i najczęściej wykorzystywanym podejściem teoretycznym w badaniach nad integracją europejską jest liberalizm. Świadczy o tym fakt, że większość współczesnych teorii integracji oraz założeń teoretycznych czerpie właśnie z paradygmatu liberalnego. Mowa tu o takich teoriach jak neofunkcjonalizm, instytucjonalizm czy liberalne podejście międzyrządowe.

Szerzej w: J. Barcz, Prawo Unii Europejskiej. Zagadnienia systemowe, Warszawa 2002, s. 395-415; J. Barcz, Butgaria i Rumunia w Unii Europejskiej. Aspekty polityczne, prawne i ekonomiczne procesu akcesyjnego, Warszawa 2009, s. 139-146.

2 A. Szymański, Unia Europejska jako wspólnota terytorialna, [w:] Europeistyka. Podręcznik akademicki, t. 2, red. K. A. Wojtaszczyk, W. Jakubowski, Warszawa 2012, s. 293-382. Szerzej w: G. Michałowska, Unia Europejska jako wspólnota obywateli, [w:] Europeistyka..., s. 181-292. 
Popularność liberalizmu wynika z jego postawy w stosunku do natury człowieka. W swej pierwotnej formie liberalizm zakładał skłonności człowieka do pokoju i integracji, a więc akcentował społeczny wymiar człowieka, nie zapominając jednocześnie o dążeniach jednostki do zapewnienia sobie korzystnej wymiany handlowej. Liberałowie przekładali ten społeczny wymiar człowieka na poziom wyższy - międzynarodowy. Uważali, że stosunki międzynarodowe są analogiczne pod względem istoty do stosunków pomiędzy jednostkami. Poza tym twierdzili, że jednostki dążą do uniknięcia konfliktów międzyludzkich poprzez demokratyzację systemów politycznych. Tym samym liberalizm właśnie, głosząc hasła demokracji i skłonności do współpracy, zyskał sobie miano teorii „matki” dla wielu współczesnych wizji integracji europejskiej ${ }^{3}$. Sformułowane przez liberałów założenia znajdują swoje odzwierciedlenie w funkcjonowaniu i realizacji polityki integracyjnej. Ponadto podkreślają znaczenie innych niż militarne instrumenty budowania wpływu na arenie międzynarodowej, co jednoznacznie pokrywa się z celem integracji europejskiej. Swoje źródło w liberalizmie ma między innymi funkcjonalizm i jego późniejsza odmiana neofunkcjonalizm. Główny myśliciel neofunkcjonalizmu, E. Haas dobitnie stwierdzał nawet, że mechanizmy integracji będą aktualne tylko w państwie liberalnym ${ }^{4}$. Pomimo tego, że większość teorii integracji europejskiej bazuje na paradygmacie liberalnym, to możliwe jest także analizowanie integracji z perspektywy realistycznej/neorealistycznej.

Celem artykułu jest zatem wykazanie złożoności procesu integracji, przez możliwość spojrzenia na tę kwestię w oparciu o różne neorealistyczne interpretacje problematyki.

Zasadnicze znaczenie dla teorii realistycznej ma przeświadczenie, iż należy postrzegać rzeczywistość jako faktyczną, „realnie” istniejącą. Według realistów interes, bezpieczeństwo, stabilizacja, suwerenność państwa stanowią największą wartość - rację stanu. To o interesy państwa, a nie interesy poszczególnych jednostek należy walczyć. Zatem racja stanu uzasadnia każde działanie, które służy realizacji tego interesu, a więc stoi ona ponad zasadami moralnymi, religijnymi czy ideologicznymi. Istotne znaczenie dla realistów ma więc zatem siła państwa. W związku z tym prymarną polityką państwa - zdaniem realistów - jest polityka bezpieczeństwa, realizowana poprzez politykę zagraniczną. Prymarność polityki

3 E. Haliżak, Liberalna wizja porządku międzynarodowego, [w:] Porządek międzynarodowy u progu XXI wieku, red. R. Kuźniar, Warszawa 2005, s. 59-83, cyt. za: P.J. Borkowski, Polityczne teorie integracji międzynarodowej, Warszawa 2007, s. 44-48, zob. także: R. Zięba, Studia europejskie z perspektywy stosunków międzynarodowych, [w:] Studia europejskie, red. K.A. Wojtaszczyk, W. Jakubowski, Warszawa 2012, s. 30-31.

4 P.J. Borkowski, Polityczne teorie integracji..., s. 46. 
bezpieczeństwa, potwierdza to, iż realiści szczególny nacisk kładą na militarne aspekty potęgi państwa. W związku z tym bezpieczeństwo jest państwocentryczne, tzn. państwo jest jedynym obiektem, któremu bezpieczeństwo ma być zapewnione i to państwo stanowić powinno gwarancję swojego bezpieczeństwa, dzięki posiadaniu odpowiedniej konsolidacji wewnętrznej, siły militarnej i umiejętności odstraszania potencjalnych agresorów. Państwa natomiast są na tyle suwerenne, że nie istnieje w rzeczywistości międzynarodowej jedno centrum decyzyjne, które byłoby w stanie zapanować nad chaosem obecnym w rzeczywistości międzynarodowej. W związku z tym w rzeczywistości międzynarodowej panuje anarchia, której przezwyciężenie jest bardzo trudne ${ }^{5}$.

$\mathrm{Z}$ powyższego jasno wynika, że podejście realistyczne ujmuje stosunki międzynarodowe jako grę o sumie zero. Jeśli jedno państwo się zbroi tzn. czuje się bezpiecznie. Natomiast trudno ten stan odnieść do jego sąsiadów, którzy w miarę wzrostu potencjału obronnego danego państwa, coraz realniej odbierają go jako zagrożenie. Jest to zatem pewien dylemat między państwami, które walczą o bezpieczeństwo. Kwestię tę rozwijał szczególnie H. Morgenthau, twórca klasycznego realizmu. Dylemat ten polegał na tym, że w sytuacji zagrożenia państwa mogą liczyć tylko na siebie. Nie ma zatem nadrzędnego suwerena, do którego mogłyby się zwrócić o pomoc. Tym samym muszą same walczyć o bezpieczeństwo, wybierając dla siebie najlepsze rozwiązanie. Zrównoważyć swą potęgę w starciu z innymi państwami, czy też przejąć nad nim kontrolę. Podjęte w tym celu przez państwo działanie narusza z kolei bezpieczeństwo innych państw oraz jego wizerunek w oczach innych podmiotów międzynarodowych ${ }^{6}$.

Interpretacja założeń szkoły realistycznej pozwala na wysnucie wniosku, że realiści sceptycznie odnosili się do możliwości dobrowolnej współpracy między państwami. Prymarność polityki bezpieczeństwa powoduje brak zainteresowania ze strony państwa i rządzących kwestiami organizacji integracyjnych. Według realistów, jeśli w sferze polityki bezpieczeństwa będą zachodziły konflikty, to idea zrealizowania projektu integracyjnego nie ma możliwości spełnienia. Brak

5 A. Wojciuk, Bezpieczeństwo w teoriach stosunków międzynarodowych, [w:] R. Kuźniar, Bezpieczeństwo międzynarodowe, Warszawa 2012, s. 416-447. Szerzej w: P.J. Borkowski, Polityczne teorie integracji..., s. 46; W. Gizicki , Polityczne uwarunkowania bezpieczeństwa europejskiego, Toruń 2008, s. 41-46; K. Żukrowska, Bezpieczeństwo międzynarodowe. Przegląd aktualnego stanu, Warszawa 2011, s. 69-71.

${ }^{6}$ W nurt klasycznego realizmu wpisują się także C. von Clausewitz oraz R. Aron, którzy stworzyli teorię wojny i pokoju; A. Wojciuk, Bezpieczeństwo w teoriach stosunków..., s. 423. Szerzej w: J. Kukułka, Teoretyczna konceptualizacja dyscypliny, [w:] idem, Teoria stosunków międzynarodowych, Warszawa 2000, s. 95-97; J. Czaputowicz, Realizm, [w:] Bezpieczeństwo międzynarodowe. Wspótczesne koncepcje, Warszawa 2012, 104-132. 
spełnienia podstawowego warunku, czyli bezpieczeństwa uniemożliwia realizację pozostałych celów państwa. „Trudno oprzeć się wrażeniu, że realiści uważali projekty integracyjne za pewne szlachetne mrzonki, które będą musiały ustąpić przed siłą faktów, zaangażowanie w nie - za stratę czasu, ewentualnie stworzenie wygodniejszych ram do odwiecznej rywalizacji pomiędzy państwami”'. Realiści nie zaprzeczali jednak możliwości współpracy pomiędzy państwami. Ich zdaniem integracja może dotyczyć kwestii technicznych, o charakterze niepolitycznym. Ponieważ w tych sferach łatwiej przezwyciężyć strukturalną nieufność właściwą stosunkom międzynarodowym. Według realistów istnieją trzy przypadki, kiedy może nastąpić współpraca. Przede wszystkim państwa powinny zdefiniować interes wspólny, jednocześnie nie zapominając o poszanowaniu interesów narodowych poszczególnych państw. Ponadto współpraca powinna przynosić korzyści. A zatem w przypadku integracji, korzyści powinny przewyższać straty spowodowane częściowym ograniczeniem suwerenności. Współpraca ma także szansę realizacji, gdy w ramach ugrupowania integracyjnego rozkład potęgi powoduje istnienie hegemona. W tej sytuacji może on realizować swoje interesy narodowe poprzez to ugrupowanie, narzucenie czy też przekonanie innych, że są to interesy wspólne. W tym przypadku współpraca może być efektywna, chociaż równocześnie będzie pochodną interesów dominującego w podsystemie państwa ${ }^{8}$.

Również późniejsza odmiana realizmu, neorealizm odnosiła się sceptycznie do procesu integracji. Krytyka integracji przez realistów doprowadziła w dyskursie naukowym do podważenia pozycji tego podejścia teoretycznego, jako rzetelnego kierunku badawczego, starającego się wyjaśniać rzeczywistość międzynarodową. „Neorealizm jako teoria głosi, że w międzynarodowej społeczności politycznej ustanowienie stałych norm jest niemożliwe lub mało prawdopodobne, zaś instytucje współpracy nie mają znaczącej autonomii. Stąd nie można sobie wyobrazić reżimu międzynarodowego o charakterze konstytucyjnym". W związku z krytycznymi uwagami pod adresem rzetelności, realiści tacy jak M. Mosser, a następnie J. Grieco, ostatecznie przyznali, że „budowa Unii Europejskiej była jedynym rozsądnym rozwiązaniem, aby w wyłaniającym się ładzie międzynarodowym Europa mogła efektywnie rywalizować z innymi ośrodkami gospodarczymi i politycznym - USA, Japonią, Chinami - do czego poszczególne państwa europejskie

P.J. Borkowski, Polityczne teorie integracji..., s. 37-38.

8 Ibidem, s. 37-38. Szerzej w: J. Stefanowicz, Ład międzynarodowy, Doświadczenie i przyszłość. Warszawa 1996, s. 135-138, 165-173, cyt. za: ibidem, s. 38-39.

9 A. Stone, What is a Supranational Constitution? An Essay in International Relations Theory, Journal of European Public Policy, 1994, Vol. 4, nr 3, cyt. za: P.J. Borkowski, Polityczne teorie integracji..., s. 41. 
były niezdolne. Wskazuje to na zewnętrzne warunkowanie integracji”. Ponadto, ten sam uczony stwierdził, że „państwa europejskie skonfrontowane ze zjednoczeniem Niemiec i tym samym wyłonieniem się w centrum Europy państwa potencjalnie znacząco silniejszego niż którykolwiek z jego partnerów, podjęły decyzję o wzmocnieniu struktur europejskich by w ten sposób ograniczać i kontrolować odradzającą się potęgę"10. J. Grieco ostatecznie poparł projekt integracji w ramach Unii Europejskiej. Ale z wypowiedzi tej wybrzmiewa to jedno z podstawowych założeń szkoły realistycznej, a mianowicie współpraca jedynie w celu zapewnienia własnemu państwu silnej pozycji wśród innych graczy politycznych, nie dopuszczenie do wzrostu potęgi przeciwnika oraz ukierunkowanie na stworzenie alternatywnego centrum ekonomicznego.

W latach dziewięćdziesiatych XX w. neorealiści skupili swoją uwagę przede wszystkim na instytucjach powstałych w wyniku procesu integracji oraz roli w nich małych państw. W wypowiedziach M. Mosser’a i J. Grieco przytoczonych poniżej jednoznacznie wynika to, co już zostało zasygnalizowane. Mianowicie państwa dążą do wzmocnienia własnej pozycji na arenie międzynarodowej, kosztem pozycji innych państw. Zarówno M. Mosser jak i J. Grieco uważali, iż wzmocnienie instytucjonalne integracji europejskiej oraz powstanie licznych norm regulujących zachowanie państw jest efektem działania małych państw członkowskich w Unii Europejskiej. Według tych badaczy, małe państwa promują współpracę w ramach integracji, ponieważ występowanie tych państw w ramach ugrupowania integracyjnego daje im większe możliwości realizacji swoich interesów - tej ich części, która może być zredefiniowana w interes wspólny. Z drugiej strony dążą do nadania kooperacji statusu instytucjonalnego, aby ochronić się przed dominacją dużych państw, w przypadku UE dawnych mocarstw europejskich. Tworzone w ramach współpracy struktury są dla małych państw gwarancją, że ich interesy będą brane pod uwagę w momencie ustanawiania interesu wspólnego Wspólno$\mathrm{ty}^{11}$. M. Mosser natomiast zwraca uwagę na to, że dla małych i słabych państw powołanie instytucji to nie tylko metoda zapewnienia sobie wpływu, ale także

10 J. Grieco, The Maastricht Treaty, Economic and Monetary Union and the Neo-Realist Research, cyt. za: ibidem, s. 42. Zob. także: A. Bógdał-Brzezińska, Neofunkcjonalne i neorealistyczne koncepcje Unii Europejskiej oraz ich krytyka, [w:] E. Haliżak, S. Parzymies, Unia Europejska. Nowy typ wspólnoty międzynarodowej, Warszawa 2002, s. 104-106.

11 J. Grieco, State Interests and Institutional Rule Trajectories: A Neorealist Interpretation of the Maastricht Treaty and European Economic and Monetary Union, [w:] red. B. Frankel, Realism: Restatement and Reneval, London 1996, s. 286, cyt. za: P.J. Borkowski, Polityczne teorie integracji..., s. 43 . 
środek do ograniczenia potęgi silnych państw, który wyklucza niektóre możliwości i formy jej użycia ${ }^{12}$.

W teoriach integracji europejskiej, również integracja prawna była wobec realistów czymś niemożliwym do zrealizowania. Zgodnie z podejściem realistów ponadnarodowe organizacje, takie jak Europejski Trybunał Sprawiedliwości (ETS), nie są w stanie skutecznie narzucić suwerennym państwom swojego stanowiska, jeśli nie jest to w ich interesie. Dla Europejskiego Trybunału Sprawiedliwości zostają zatem zadania stricte pomocnicze, np. stosowanie przepisów traktatowych i prawa pochodnego stanowionych przez państwa członkowskie ${ }^{13}$. Ponadto pojęcie ponadnarodowego prawa wspólnotowego według realistów nie funkcjonuje, gdyż krajowe ustawodawstwo jest zdolne ograniczyć skuteczność lub unieważnić regulację prawa wspólnotowego, a sądy krajowe nie mają obowiązku jego stosowania ${ }^{14}$. Realizm podtrzymuje zatem twierdzenie o wyższości krajowej władzy politycznej nad prawem wspólnotowym. Ponadnarodowe organizacje są zatem nieskuteczne $\mathrm{w}$ forsowaniu procesu integracji w stosunku do suwerennych państw, w sytuacji, gdy nie jest to zgodne z ich interesem i priorytetami rozwojowymi ${ }^{15}$. Analizą problematyki funkcjonowania ETS zajmowali się także neorealiści G. Garrett oraz B. Weingast. Sformułowali oni tezę, iż działalność tej instytucji odzwierciedla kalkulacje interesów narodowych reprezentowanych przez państwa członkowskie. G. Garrett podkreśla w szczególności brak jakichkolwiek autonomicznych uprawnień Trybunału do wpływania na postępowanie krajowych aktorów politycznych w ramach Wspólnoty. Natomiast utrzymywanie systemu prawnego Wspólnoty jest możliwe tylko dlatego, iż jest on zgodny z interesami państw członkowskich. Ponadto w interesie państw członkowskich jest delegowanie na rzecz ETS kompetencji badania naruszania obowiązków traktatowych przez państwa członkowskie. Dalsze prace G. Garretta nad funkcjonowaniem ETS doprowadziły go do postawienia tezy, iż ETS forsuje działania prointegracyjne narzucane przez najbardziej wpływowych członków Unii Europejskiej, a więc Francję i Niemcy, bez uwzględniania stanowiska pozostałych państw. Jednocześnie taka działalność stwarza niebezpieczeństwo dla ETS w postaci ignorowania jego orzeczeń przez

12 M. Mosser, Engineering Influence: The Subtle Power of Smaller States in International Relations, Chapter Hill 2000, cyt. za: ibidem, s. 43.

13 J.H.H. Weiler, Community, Member States and European Integration: Is the Law Relevant?, Journal of Common Market Studies, 1982, Vol. 21, s. 39-56, cyt za: F. Strzyczkowski, Teorie integracji europejskiej $w$ doktrynie amerykańskiej, Warszawa 2012, s. 142.

14 P. Taylor, The Limit of European Integration, New York 1983, s. 280, cyt. za: ibidem, s. 142.

15 W. Mattli, A.M. Slaughter, Revisiting the European Court of Justices, International Organization, 1998, Vol. 52, nr 1, s. 180, cyt. za: ibidem, s. 142. 
pozostałe, mniej wpływowe państwa członkowskie. W celu zminimalizowania tego niebezpieczeństwa ETS stara się godzić interesy poszczególnych państw ${ }^{16}$.

Z powyższego jasno wynika, iż realistyczne i neorealistyczne podejście do badania integracji w ramach Unii Europejskiej zakłada analizę rzeczywistości międzynarodowej z szerokiej perspektywy. W związku z tym zachowanie jednostek w systemie międzynarodowym należy badać w oparciu o analizę całej struktury owego systemu. Neorealizm szeroko korzystał z dorobku tzw. szkoły systemowej, często więc zamiennie nurt ten nazywany był realizmem strukturalnym. Rzeczywistość międzynarodowa, rozumiana jako pewnego rodzaju struktura bądź system musi być ujęta w sposób holistyczny. Holistyczne ujęcie bowiem, zwraca uwagę na relacyjne powiązania z innymi elementami systemu i ich rolę w szerzej całości. Zachodzące współcześnie w ramach Unii Europejskiej procesy integracyjne, są ustrukturyzowane i stanowią pewnego rodzaju system wspólnych zależności.

Tak jak zostało zasygnalizowane powyżej integracja jest procesem dynamicznym i długotrwałym, wymagającym wielu zmian na poziomie narodowym jak i ponadnarodowym, dlatego też analizowanie tego procesu z pominięciem szerokiej perspektywy wydaje się być zadaniem daremnym. W związku z tym, że integracja jest procesem, a więc pewnego rodzaju systemem działania to na proces ten oddziałuje wiele czynników. Można powiedzieć, za D. Eastonem, że integrację stanowią „wejścia” i „wyjścia” do owego systemu (tu: integracji) oraz otoczenie danego systemu ${ }^{17}$. Przekładając to systemowe ujęcie na realistyczne i neorealistyczne interpretacje integracji europejskiej śmiało można powiedzieć, że oba podejścia ujmują rzeczywistość międzynarodową w kategoriach struktury, a więc elementów, które wzajemnie na siebie wpływają. Oba podejścia kładą szczególny nacisk na potęgę i siłę militarną państwa. Siła ta jednak zawsze definiowana jest w odniesieniu do innych państw. W tym kontekście pojawia się omawiany powyżej model stosunków międzynarodowych jako gry o sumie zero. Siła jednego państwa wpływa na pozycję państwa drugiego. Niewątpliwie jest to zatem pewna struktura, system, który analizowany powinien być całościowo.

16 Szerzej nt. analiz G. Garretta i B. Weingasta oraz polemiki z twierdzeniami obu badaczy ibidem, s. 143-146.

${ }_{17}$ Szerzej w: K. Opałek, Metodologiczne i teoretyczne problemy nauk politycznych, Warszawa 1975; A. Szymański, Analiza systemowa w badaniach politologicznych nad problematyka europejska, Przegląd Europejski, 2006, nr 2, s. 98-107. 